Позняковська Н. М., к.е.н., доцент, Підгрушний В. А., здобувач II-го (магістерського) рівня вищої освіти спеціальності 071 «Облік і оподаткування» (Національний університет водного господарства та природокористування, м. Рівне)

\title{
РЕФОРМУВАННЯ БУХГАЛТЕРСЬКОГО ОБЛІКУ УСТАНОВ ДЕРЖАВНОГО СЕКТОРУ ЯК НЕВІД'ЄМНА СКЛАДОВА ЄВРОІНТЕГРАЦІЙНИХ ПРОЦЕСІВ
}

У статті розглядаються питання реформування бухгалтерського обліку суб'єктів державного сектору України на підставі Міжнародних стандартів бухгалтерського обліку у державному секторі. Названо основні проблеми бухгалтерського обліку суб'єктів державного сектору. Розглянуто облікову політику суб'єктів державного сектору України.

Ключові слова: суб'єкт державного сектору, національні положення (стандарти) бухгалтерського обліку у державному секторі, Міжнародні стандарти бухгалтерського обліку у державному секторі, облікова політика.

Постановка проблеми. В Україні триває адаптація бухгалтерського обліку в державному секторі до Міжнародних стандартів бухгалтерського обліку для державного сектору (МСБОДС). Відліком активного реформування бухгалтерського обліку є прийняття у 2007 році Постанови Кабінету Міністрів України № 34 «Про затвердження Стратегії модернізації системи бухгалтерського обліку в державному секторі України на 2007-2015 роки» [1]. У 2018 році запроваджено Розпорядження Кабінету Міністрів України № 437-р «Про схвалення Стратегії модернізації системи бухгалтерського обліку та фінансової звітності в державному секторі на період до 2025 року» [2]. Передумовами широкомасштабного реформування стали: застосування різних методів ведення бухгалтерського обліку, як то, касового та методу нарахувань; ведення бухгалтерського обліку з виконання бюджетів, розпорядниками бюджетних коштів та фондами загальнообов'язкового державного соціального та пенсійного страхування за різними Планами рахунків; практика подвійної консолідації фінансової звітності; відсутність єдиного підходу щодо використання програмного продукту для здійснення облікових операцій у державному секторі. 
Реформування передбачає комплекс заходів, зокрема запровадження національних стандартів бухгалтерського обліку в державному секторі (НП(С)БОДС) на основі міжнародних стандартів. На сьогодні в державному секторі діє 20 національних положень (стандартів) бухгалтерського обліку) та методичні рекомендації щодо їх застосування. На виконання Стратегії затверджений План рахунків бухгалтерського обліку в державному секторі, який передбачає відображення інформації про операції з виконання бюджетів, розпорядників бюджетних коштів та фондів загальнообов'язкового державного соціального та пенсійного страхування, та порядок застосування Плану рахунків. Сьогодні використовується План рахунків бухгалтерського обліку в державному секторі, затверджений наказом Міністерства фінансів України від 31.12.2013 року № 1203 [3] та Порядок застосування Плану рахунків бухгалтерського обліку в державному секторі та Типова кореспонденція субрахунків бухгалтерського обліку для відображення операцій 3 активами, капіталом та зобов'язаннями розпорядниками бюджетних коштів та державними цільовими фондами, затверджені Міністерством фінансів України від 29.12.2015 року № 1219 [4]. Для допомоги розпорядникам бюджетних коштів підготовлені Методичні рекомендації зі співставлення субрахунків бухгалтерського обліку та перенесення залишків, які затверджені наказом Міністерством фінансів України від 21.12.2016 року № 1127 [5]. Установи державного сектору заповнюють нові форми фінансової звітності відповідно до Порядку заповнення форм фінансової звітності в державному секторі 2017 року [6].

На сьогодні залишаються невирішені питання, зокрема застосування методу нарахування для обліку доходів та витрат бюджетних установ; визначення структури консолідованої фінансової звітності та її формування суб'єктами державного сектору. Актуальною проблемою $є$ створення уніфікованого програмного продукту з ведення бухгалтерського обліку та складання фінансової звітності розпорядниками бюджетних коштів та фондами загальнообов'язкового державного соціального та пенсійного страхування з інтеграцією до облікової системи Казначейства і системи подання фінансової звітності в електронному форматі.

Аналіз останніх досліджень та публікацій. Різним аспектам реформування системи бухгалтерського обліку державного сектора економіки, його гармонізації із Міжнародними стандартами присвячені праці таких вчених, як Калюги Є., Ловінської Л., Єфименко Т., Джоги Р., Лемішовського В., Свірко С., Сушко Н., Соколова Я., Чечуліної О., інших. Однак, залишаються актуальними питання реформу- 
вання бухгалтерського обліку суб'єктів державного сектору України, дослідження відповідності облікової політики вітчизняних установ до рекомендацій Міжнародних стандартів та кращої світової практики.

Метою статті $є$ дослідження основних питань і проблем реформування бухгалтерського обліку суб'єктів державного сектору на підставі Міжнародних стандартів бухгалтерського обліку державного сектору.

Виклад основного матеріалу. Стратегія модернізації системи бухгалтерського обліку та фінансової звітності в державному секторі України передбачає План заходів щодо модернізації системи бухгалтерського обліку та фінансової звітності в державному секторі на період до 2025 року.

Важливим етапом організації бухгалтерського обліку в бюджетній установі $\epsilon$ затвердження облікової політики. Особливу увагу варто акцентувати на впровадження НП(С)БОДС 125 «Зміни облікових оцінок та виправлення помилок» [7], відповідно до якого бюджетна установа повинна розробити розпорядчий документ, встановивши методи оцінки, обліку та процедури, які використовуються установою та щодо яких нормативно-правовими актами з бухгалтерського обліку визначено більше ніж один варіант. Усі ці питання бюджетна установа повинна врегулювати у положенні про облікову політику.

Міністерство фінансів України затвердило Методичні рекомендації щодо облікової політики суб'єкта державного сектора [8], які визначили орієнтовний перелік питань, що підлягають розкриттю в наказі про облікову політику. Однак такий перелік не $є$ повним, і залежить від особливостей діяльності установи, враховуючи те, що розпорядник бюджетних коштів нижчого рівня повинен взяти за основу вимоги головного розпорядника бюджетних коштів вищого рівня. Якщо такі вимоги відсутні, то установі слід прийняти власний розпорядчий документ про організацію обліку та облікову політику, враховуючи вимоги законодавчих актів та виходячи з професійного судження головного бухгалтера. Тоді у примітках до фінансової звітності необхідно розкрити облікову політику за кожним об'єктом шляхом опису застосовуваних установою принципів оцінки статей звітності та методів обліку окремих активів та зобов'язань, причини та суть зміни облікової політики.

Вітчизняні науковці по-різному визначають назву та структуру розпорядчого документа, яким регламентується бухгалтерський облік. Як правило, виділяють два основних виміри: 1) методичний, на якому здійснюється вибір системи певних способів та прийомів, в основі яких лежать методи бухгалтерського обліку; 2) організацій- 
ний, який передбачає визначення структури бухгалтерії та розподіл обов'язків між її працівниками та включає вибір форми бухгалтерського обліку, вибір способу обробки облікових даних, розробка переліку та форм облікових регістрів.

Вважаємо за доцільне питання організації обліку в установі, правила документообігу, робочий план рахунків викласти в окремому наказі про організацію бухгалтерського обліку. Такий підхід відповідає положенням НП(с)БОДС 125 та Методичним рекомендаціям щодо облікової політики Міністерства фінансів України. В розділі II Методичних рекомендацій чітко зазначений перелік питань, які підлягають розкриттю, і які не можуть бути ідентифіковані як аспекти організації бухгалтерського обліку в установі. Чи є такий підхід правильним?

В. С. Олійник [9] припускає, що це пов'язано з частою зміною питань організації бухгалтерського обліку. С. Я. Зубілевич [10] зазначає, що такий підхід пов'язаний із консолідацією фінансових звітів розпорядників бюджетних коштів нижчого рівня у межах головного розпорядника бюджетних коштів, згідно з якою останній повинен встановити єдину для усіх підпорядкованих суб'єктів державного сектора облікову політику. Тому при створенні документа, який регламентує організацію обліку в установі, як і облікову політику, розпорядник бюджетних коштів повинен врахувати необхідність погодження наказу головним розпорядником бюджетних коштів та дотримуватися суворої регламентації організації обліку та звітності 3 боку Міністерства фінансів України та Державної казначейської служби. Тобто бюджетні установи апріорі є обмеженими у виборі альтернативних методів та способів оцінки активів, створення резервів, методів нарахування зносу, вибору облікових регістрів чи інших питань методології бухгалтерського обліку.

В Україні більшість питань організації та методики обліку в бюджетних установах визначені на рівні законодавства та підзаконних нормативно-правових актів, що утруднює можливості самостійно регулювати бухгалтерський облік на рівні розпорядників бюджетних коштів нижчого рівня. Це є однією з відмінностей від кращої світової практики. Адже МСБОДС не містять вказівок щодо організації та техніки обліку.

В частині організації бухгалтерського обліку вітчизняні установи повинні навести дані про джерела фінансування; особу, на яку покладено обов'язки ведення бухгалтерського обліку; перелік чинних нормативно-правових актів, на підставі яких здійснюється організація та ведення бухгалтерського обліку; зазначити форму ведення 
бухгалтерського обліку та спосіб обробки облікових даних (як правило, меморіально-ордерна форма без використання спеціалізованого програмного забезпечення або комп'ютеризована); форму організації бухгалтерського обліку (централізована бухгалтерія, бухгалтерська служба чи спеціаліст, на якого покладається виконання завдань та функціональних обов'язків); порядок та терміни проведення інвентаризації активів та зобов'язань; перелік посадових осіб, які мають право розпоряджатися рахунками та підписувати платіжні, розрахункові та інші первинні документи, бюджетну та фінансову звітність; визначити порядок видачі підзвітних сум; визначити форми робочих документів, відмінних від типових, та тих, що розроблені установою самостійно; порядок створення постійно діючої комісії (інвентаризаційної, тарифікаційної, з приймання в експлуатацію необоротних активів, списання матеріальних цінностей). В додатках навести робочий план рахунків бухгалтерського обліку установи, графік документообігу первинних документів, регістрів аналітичного та синтетичного обліку, форм фінансової та бюджетної звітності; додаткові регістри аналітичного обліку для деталізації надходжень та витрат за видами платних послуг; положення про порядок преміювання, надання матеріальної допомоги та встановлення надбавок і доплат до посадових окладів працівникам установи; положення про архів установи; керівництво 3 інших питань (визначення ліміту залишку готівки в касі).

31 січня 2017 року кожна бюджетна установа повинна використовувати власний Робочий план рахунків шляхом введення до субрахунків чинного Плану рахунків аналітичних рахунків (наприклад, для обліку операцій за загальним та спеціальним фондами). Тобто структура аналітичних рахунків повинна забезпечити деталізацію інформації про кошти, грошові документи, розрахунки, інші доходи та витрати, доходи та витрати від обмінних та необмінних операцій, майбутніх періодів, витрати на амортизацію та матеріальні цінності за загальним та спеціальним фондами та кодами програмної та економічної класифікації видатків бюджету. Також така структура допоможе деталізувати інформацію за коштами спеціального фонду (групами, підгрупами). Дану інформацію необхідно відобразити в обліковій політиці установи. Перелік субрахунків у вигляді робочого плану субрахунків затверджується наказом чи розпорядженням про організацію бухгалтерського обліку.

У зв'язку з впровадженням низки НП(С)БОДС, бюджетні установи у 2017 році вимушені були внести певні зміни до облікової політики. Відповідно до НП(С)БОДС 125 облікова політика може змінюватися тільки у разі, якщо змінюються вимоги положення (статуту), вимо- 
ги органу, який затверджує національні положення (стандарти) бухгалтерського обліку в державному секторі, або якщо такі зміни забезпечать достовірне відображення подій чи господарських операцій у фінансовій звітності суб'єкта державного сектору. Якщо такі зміни $€$, то $€$ два способи їх відображення: перспективний та ретроспективний. Відповідно до перспективного нова облікова політика застосовується тільки до тих подій та операцій, що виникають після, або/і в момент затвердження цих змін із відсутністю необхідності коригування сальдо фінансового результату попереднього періоду. Ретроспективний спосіб передбачає внесення змін до подій та господарських операцій, проведених до нової облікової політики шляхом коригування сальдо фінансових результатів попередніх періодів, повторному поданні порівняльної інформації стосовно попередніх звітних періодів. Всі зміни мають бути розкриті у примітках до річної фінансової звітності.

Введення у практику бухгалтерського обліку нових стандартів спричинило зміни в методології обліку бюджетних установ, зокрема суттєвих змін зазнала методологія обліку доходів та витрат. Серед них особливу увагу звертаємо на НП(С)БОДС 124 «Доходи» [11] та НП(С)БОДС 135 «Витрати» [12], які закладають принципово інші підходи до визнання, оцінки та бухгалтерського обліку відповідно доходів та витрат бюджетних установ.

Відповідно до НП(С)БОДС 101 «Подання фінансової звітності» [13], доходи та витрати бюджетних установ класифікуються за операціями обміну. Відповідно до доходів від обмінних операцій відносимо: бюджетні асигнування; доходи від надання послуг (виконання робіт); доходи від продажу; доходи від відсотків, роялті та дивідендів (попередньо такий вид доходів не виділявся, і поки не регламентований законодавчо) та інші доходи від обмінних операцій. Доходи від необмінних операцій включають: податкові надходження; неподаткові надходження (збори та платежі); трансферти та кошти, отримані від підприємств, організацій, фізичних осіб та інших бюджетних установ для виконання цільових заходів; надходження до державних цільових фондів та зобов'язання, що не підлягають погашенню.

Це загальна класифікація, однак в обліковій політиці конкретної установи (органу місцевого самоврядування, закладу вищої освіти чи медичного закладу) доцільно подати уточнений склад доходів від обмінних операцій: доходи від надання послуг (плата за послуги, що надаються бюджетними установами згідно з їх основною діяльністю; надходження бюджетних установ від додаткової діяльності; плата за оренду майна бюджетних установ); доходи від відсотків, ро- 
ялті та дивідендів (кошти від розміщення на депозитах тимчасово вільних коштів; відсотки на залишок коштів на поточних рахунках; благодійні внески та гранти); інші доходи (доходи від курсових різниць; доходи за сумами зобов'язань бюджету; доходи від списання кредиторської заборгованості, строк позовної давності якої минув; доходи від переоцінки активів установ). Актуально в частині облікової політики врегулювати питання визначення доходів за загальним та спеціальним фондами.

В обліковій політиці щодо витрат пропонуємо вирішити питання визначення складу витрат, або їх класифікаційні групи, які належать до необмінних операцій, враховуючи специфіку діяльності установи, визначити порядок групування інформації про витрати від надання послуг (за групами послуг, елементами витрат, статтями калькуляції, центром виникнення витрат, темами договорів, календарними періодами), врегулювати питання визначення порядку визнання витрат (чи визнавати витрати одночасно з отриманням доходу чи виходячи з умов договору та ступеня завершеності операцій з надання послуг на дату балансу). Необхідно врегулювати в частині облікової політики витрат питання визначення переліку витрат загальним та спеціальними фондами.

Вважаємо за доцільне ввести додаткові субрахунки для розмежування операцій за умови, що установа має декілька бюджетних програм. Сьогодні на виконання Концепції реформування місцевого самоврядування та територіальної організації влади в Україні, затвердженої розпорядженням Кабінету Міністрів України від 01.04.2014 року № 333-р [14], здійснюється перехід до планування бюджету на середньострокову перспективу, що передбачає застосування у бюджетному процесі програмно-цільового методу, як методу управління бюджетними коштами для досягнення конкретних результатів за рахунок коштів бюджету із застосування оцінки ефективності використання бюджетних коштів на всіх рівнях бюджетного процесу. В рамках методу використовуються бюджетні програми. 3окрема, в Бродівській районній раді на 2018 рік діє програма за кодом програмної класифікації видатків та кредитування місцевих бюджетів 0110150 «Організаційні, інформаційно-аналітичне та матеріально-технічне забезпечення діяльності обласної ради, районної ради, районної у місті ради (у разі її створення), міської, селищної, сільської рад».

На підставі синтетичних рахунків для обліку витрат бюджету/кошторису варто розширити застосування аналітичних рахунків. Це сприятиме раціональному та ефективному використанню коштів бюджету та їх відображенню в бухгалтерському обліку. Окремим пу- 
нктом в обліковій політиці бюджетних установ, які надають послуги, виробляють товари необхідно встановити перелік та склад статей калькуляції виробничої собівартості продукції (робіт, послуг). Важливо обрати спосіб розподілу непрямих витрат між окремими об'єктами обліку та калькулювання і визначити базу їх розподілу.

В якості додатків до облікової політики установи необхідно навести: 1. Порядок відкриття аналітичних рахунків районної ради. 2. Робочу схему кореспонденції субрахунків установи. 3. Відомість строків корисного використання груп основних засобів установи.

Висновки. В Україні триває процес реформування системи бухгалтерського обліку в державному секторі. Важливою складовою модернізації стало впровадження національних положень (стандартів) бухгалтерського обліку, адаптованих до міжнародних стандартів. Нові стандарти змінюють підходи щодо оцінки та визнання об'єктів обліку, зокрема доходів та витрат, як основних показників діяльності установи. Вперше на законодавчому рівні у системі бухгалтерського обліку державного сектору ідентифіковане поняття «витрати», однак залишається невирішеним питанням використання в обліку витрат водночас двох методів - нарахування та касового. Використання методу нарахування $€$ виправданим з боку міжнародних стандартів, однак сьогодні цей метод не $\epsilon$ імплементованим у вітчизняну систему обліку в державному секторі.

Важливою складовою раціональної організації бухгалтерського обліку є формування наказу про організацію обліку та облікову політику, який визначить основні принципи та підходи до організації обліку в установі та принципи, методи і процедури бухгалтерського обліку тих об'єктів, щодо яких існують певні альтернативні варіанти. В обліковій політиці щодо обліку доходів і витрат бюджетна установа повинна навести класифікаційні ознаки, або класифікаційні групи, які належать до обмінних та необмінних операцій, визначити порядок групування інформації про витрати від надання послуг; уточнити склад доходів від обмінних операцій; розробити перелік витрат та доходів за загальним та спеціальним фондами.

1. Про затвердження Стратегії модернізації системи бухгалтерського обліку в державному сектору України на 2007-2015 роки : Постанова Кабінету Міністрів України від 16.01.2017 р. № 34. URL: http://zakon1.rada. gov.ua. (дата звернення: 15.05.2019). 2. Про схвалення Стратегії модернізації системи бухгалтерського обліку та фінансової звітності в державному секторі на період до 2025 року : розпорядження Кабінету Міністрів України від 20.03.2018 p. № 437-p. URL: http://zakon1.rada. gov.ua. (дата звернення: 
15.05.2019). 3. План рахунків бухгалтерського обліку в державному секторі : наказ Міністерства фінансів України від 31.12.2013 року № 1203. URL: https://buhgalter.com.ua/zakonodavstvo/buhgalterskiy-oblik/ (дата звернення: 15.05.2019). 4. Порядок застосування Плану рахунків бухгалтерського обліку в державному секторі. Типова кореспонденція субрахунків бухгалтерського обліку для відображення операцій з активами, капіталом та зобов'язаннями розпорядниками бюджетних коштів та державними цільовими фондами : наказ Міністерства фінансів України від 29.12.2015 року № 1219. URL: https://buhgalter.com.ua/zakonodavstvo/buhgalterskiy-oblik/ (дата звернення: 15.05.2019). 5. Методичні рекомендації зі співставлення субрахунків бухгалтерського обліку та перенесення залишків : наказ Міністерством фінансів України від 21.12.2016 року № 1127. URL: https://buhgalter.com.ua/zakonodavstvo/buhgalterskiy-oblik/ (дата звернення: 15.05.2019). 6. Порядок заповнення форм фінансової звітності в державному секторі : наказ Міністерства фінансів України від 28.02.2017 року № 307. URL: https://buhgalter.com.ua/zakonodavstvo/natsstandarti-buhoblikuv-derzhavnomu-sektori/poryadok-zapovnennya-form-finansovoyi-zvitnosti-vderzhavnomu-sektori/. (дата звернення: 15.05.2019). 7. Про затвердження Національного положення (стандарту) бухгалтерського обліку в державному секторі 125 «Зміни облікових оцінок та виправлення помилок» : наказ Міністерства фінансів України від 24.12.2010 р. № 1629. URL: http://zakon1.rada. gov.ua. (дата звернення: 15.05.2019). 8. Про затвердження Методичних рекомендацій щодо облікової політики суб'єкта державного сектору : наказ Міністерства фінансів України від 23.01.2015 p. № 11. URL: http://zakon1.rada. gov.ua. (дата звернення: 15.05.2019). 9. Олійник В. С. Облікова політика як основа бухгалтерського обліку виплат працівникам у кримінально-виконавчих установах. Управління розвитком. 2016. № 2. C. 96-101. URL: http://nbuv.gov.ua/UJRN/Uproz_2016_2_16. (дата звернення: 15.05.2019). 10. Зубілевич С. Я. Особливості формування розпорядчих документів щодо облікової політики та організації обліку бюджетних установ. Облік оподаткування і контроль: теорія та методологія : Міжнародна науково-практична Інтернет-конференція. (Тернопіль, 30 червня 2017 року). 2017. C. 112-115. URL: http://dspace.tneu.edu.ua/bitstream/316497/22021/1/112-115.pdf. (дата звернення: 15.05.2019). 11. Про затвердження Національного положення (стандарту) бухгалтерського обліку в державному секторі 124 «Доходи»: наказ Міністерства фінансів України від 24.12.2010р. № 1629. URL: http://zakon1.rada. gov.ua. (дата звернення: 15.05.2019). 12. Про затвердження Національного положення (стандарту) бухгалтерського обліку в державному секторі 135 «Витрати» : наказ Міністерства фінансів України від 18.05.2012 р. № 2010. URL: http://zakon1.rada. gov.ua. (дата звернення: 15.05.2019). 13. Про затвердження Національного положення (стандарту) бухгалтерського обліку в державному сектору 101 «Подання фінансової звітності» : наказ Міністерства фінансів України від 28.12.2009 р. № 1541, 
наказ Міністерства фінансів України від 24.12.2010 р. № 1629. URL: http://zakon1.rada. gov.ua. (дата звернення: 15.05.2019). 14. Про схвалення Концепції реформування місцевого самоврядування та територіальної організації влади в Україні: розпорядження Кабінету Міністрів України від 01.04.2014 p. № 333-p. URL: http://zakon1.rada. gov.ua. (дата звернення: 15.05.2019).

\section{REFERENCES:}

1. Pro zatverdzhennia Stratehii modernizatsii systemy bukhhalterskoho obliku v derzhavnomu sektoru Ukrainy na 2007-2015 roky : Postanova Kabinetu Ministriv Ukrainy vid 16.01.2017 r. № 34. URL: http://zakon1.rada. gov.ua. (data zvernennia: 15.05.2019). 2. Pro skhvalennia Stratehii modernizatsii systemy bukhhalterskoho obliku ta finansovoi zvitnosti v derzhavnomu sektori na period do 2025 roku : rozporiadzhennia Kabinetu Ministriv Ukrainy vid 20.03.2018 r. № 437-r. URL: http://zakon1.rada. gov.ua. (data zvernennia: 15.05.2019). 3. Plan rakhunkiv bukhhalterskoho obliku $v$ derzhavnomu sektori : nakaz Ministerstva finansiv Ukrainy vid 31.12.2013 roku № 1203. URL: https://buhgalter.com.ua/zakonodavstvo/buhgalterskiy-oblik/ (data zvernennia: 15.05.2019). 4. Poriadok zastosuvannia Planu rakhunkiv bukhhalterskoho obliku $v$ derzhavnomu sektori. Typova korespondentsiia subrakhunkiv bukhhalterskoho obliku dlia vidobrazhennia operatsii z aktyvamy, kapitalom ta zo-boviazanniamy rozporiadnykamy biudzhetnykh koshtiv ta derzhavnymy tsilovymy fondamy : nakaz Ministerstva finansiv Ukrainy vid 29.12.2015 roku № 1219. URL: https://buhgalter.com.ua/zakonodavstvo/buhgalterskiy-oblik/ (data zvernennia: 15.05.2019). 5. Metodychni rekomendatsii zi spivstavlennia subrakhunkiv bukhhalterskoho obliku ta perenesennia zalyshkiv : nakaz Ministerstvom finansiv Ukrainy vid 21.12.2016 roku № 1127. URL: https://buhgalter.com.ua/zakonodavstvo/buhgalterskiy-oblik/ (data zvernennia: 15.05.2019). 6. Poriadok zapovnennia form finansovoi zvitnosti v derzhavnomu sektori : nakaz Ministerstva finansiv Ukrainy vid 28.02.2017 roku № 307. URL: https://buhgalter.com.ua/zakonodavstvo/natsstandartibuhobliku-v-derzhavnomu-sektori/poryadok-zapovnennya-form-finansovoyizvitnosti-v-derzhavnomu-sektori/. (data zvernennia: 15.05.2019). 7. Pro zatverdzhennia Natsionalnoho polozhennia (standartu) bukhhalterskoho obliku v derzhavno-mu sektori 125 «Zminy oblikovykh otsinok ta vypravlennia pomylok» : nakaz Ministerstva finansiv Ukrainy vid 24.12.2010 r. № 1629. URL: http://zakon1.rada. gov.ua. (data zvernennia: 15.05.2019). 8. Pro zatverdzhennia Metodychnykh rekomendatsii shchodo oblikovoi polityky subiekta derzhavnoho sektoru : nakaz Ministerstva finansiv Ukrainy vid 23.01.2015 r. № 11. URL: http://zakon1.rada. gov.ua. (data zvernennia: 15.05.2019). 9. Oliinyk V. S. Oblikova polityka yak osnova bukhhalterskoho obliku vyplat pratsivnykam u kryminalno-vykonavchykh ustanovakh. Upravlinnia rozvytkom. 2016. № 2. S. 96-101. URL: http://nbuv.gov.ua/UJRN/Uproz_2016_2_16. (data zvernennia: 
15.05.2019). 10. Zubilevych S. Ya. Osoblyvosti formuvannia rozporiadchykh dokumentiv shchodo oblikovoi polityky ta orhanizatsii obliku biudzhetnykh ustanov. Oblik opodatkuvannia i kontrol: teoriia ta metodolohiia : Mizhnarodna naukovo-praktychna Internet-konferentsiia. (Ternopil, 30 chervnia 2017 roku). $2017 . \quad$ S. 112-115. URL: http://dspace.tneu.edu.ua/bitstream/316497/22021/1/112-115.pdf. (data zvernennia: 15.05.2019). 11. Pro zatverdzhennia Natsionalnoho polozhennia (standartu) bukhhalterskoho obliku v derzhavnomu sektori 124 «Dokhody» : nakaz Ministerstva finansiv Ukrainy vid 24.12.2010 r. № 1629. URL: http://zakon1.rada. gov.ua. (data zvernennia: 15.05.2019). 12. Pro zatverdzhennia Natsionalnoho polozhennia (standartu) bukhhalterskoho obliku $v$ derzhavnomu sektori 135 «Vytraty» : nakaz Ministerstva finansiv Ukrainy vid 18.05.2012 r. № 2010. URL: http://zakon1.rada. gov.ua. (data zvernennia: 15.05.2019). 13. Pro zatverdzhennia Natsionalnoho polozhennia (standartu) bukhhalterskoho obliku v derzhavnomu sektoru 101 «Podannia finansovoi zvitnosti»: nakaz Ministerstva finansiv Ukrainy vid 28.12.2009 r. № 1541, nakaz Ministerstva finansiv Ukrainy vid 24.12.2010 r. № 1629. URL: http://zakon1.rada. gov.ua. (data zvernennia: 15.05.2019). 14. Pro skhvalennia Kontseptsii reformuvannia mistsevoho samovriaduvannia ta terytorialnoi orhanizatsii vlady v Ukraini: rozporiadzhennia Kabinetu Ministriv Ukrainy vid 01.04.2014 r. № 333-r. URL: http://zakon1.rada. gov.ua. (data zvernennia: 15.05.2019).

Рецензент: к.е.н., професор Зубілевич С. Я. (НУВГП)

Pozniakovska N. M., Candidate of Economics (Ph.D.), Associate Professor, Pidhrushnyi V. A., Applicant (National University of Water and Environmental Engineering, Rivne)

THE ACCOUNTING IN PUBLIC SECTOR REFORMS ARE A COMPONENT OF THE EUROPEAN INTEGRATION PROCESS

The accounting in government sector reforms on the basis International Public Sector Accounting are researched in the article. The main problems of accounting in government sector are identified. The accounting policies in government sector are considered in the article.

Keywords: Public Sector, national standards public sector accounting International Public Sector Accounting, accounting policy. 
Позняковская Н. Н., к.э.н., доцент Пидгрушный В. А., студент 2-го (магистерского) уровня высшего образования специальности «Учет и налогообложение» (Национальный университет водного хозяйства и природопользования, г. Ровно)

\section{РЕФОРМИРОВАНИЕ БУХГАЛТЕРСКОГО УЧЕТА УЧРЕЖДЕНИЙ ГОСУДАРСТВЕННОГО СЕКТОРА КАК НЕОТЪЕМЛЕМАЯ ЧАСТЬ ЕВРОИНТЕГРАЦИОННЫХ ПРОЦЕССОВ}

В статье рассматриваются вопросы реформирования бухгалтерского учета субъектов государственного сектора Украины на основе Международных стандартов бухгалтерского учета в государственном секторе. Названы основные проблемы бухгалтерского учета субъектов государственного сектора в Украине. Рассмотрено учетную политику субъектов государственного сектора.

Ключевые слова: субъект государственного сектора, национальные положения (стандарты) бухгалтерского учета в государственном секторе, учетная политика. 